\title{
International Dynamic Marketing Capabilities of Emerging- Market Small Business on E-commerce
}

\author{
Kihyon Kim ${ }^{1}$, Gyoo Gun Lim ${ }^{1}$ * \\ 1 Business School, Hanyang University, 222 Wangsimni-ro, Seongdong-gu, Seoul, Republic of Korea; kihyon \\ @hanyang.ac.kr \\ * Correspondence: gglim@hanyang.ac.kr
}

\begin{abstract}
For better export marketing strategies (EMS), companies mobilize their internal resources, which are managerial commitment, firm experience, and product uniqueness. However, Small businesses with constrained resources cannot be well explained with this view. So, more research on how small business come up with EMS have been called for. To explain how resource-restricted firms which rely heavely on entrepreneur, this study adopted the concept of dynamic managerial capabilities (DMCs) and resource versatility to better explain small business exports. We analyzed small businesses in Mongolia with qualitative research methods, including interviews with entrepreneurs and support organizations, site visits, and group discussions. We suggest international dynamic marketing capabilities (IDMCs), which are entrepreneurial orientation, networking capability, and versatile dynamic capability for small business. Theoretical and managerial implications are discussed.
\end{abstract}

Keywords: Cross-Border Electronic Commerce (CBEC); Export Marketing Strategy (EMS); International Dynamic Marketing Capability (IDMC); Dynamic Managerial Capability (DMC); Entrepreneurial Orientation; Networking Capability; Versatile Dynamic Capability

\section{Introduction}

Cross-border electronic commerce (CBEC; e-commerce), which is an online channel through which products are directly sold to international consumers via the internet, is expected to account for $22 \%$ of the total business-to-consumer (B2C) e-commerce worldwide by 2022 [46]. CBEC has profound impacts on a country's trade growth [96], economic progress [104] and even more important developing countries [66]. CBEC is a way to diversify against unstable situations in domestic markets for small businesses in emerging markets [25]. Therefore, successful CBEC is important for small businesses in emerging economies.

For high level of export performance, it has been proved that export marketing strategies (EMS) is critical [35]. Many reseraches have focused on internal resources of firms that determines the adoption of EMS [75]. For example, managerial commitment, firm experience, and product uniqueness have proven to lead to the adoption of EMS, thus resulting high export performance $[47,54]$.

However, although CBEC is important for small business, they have limited resources compared to large companies $[12,32,69,84]$. Considerign their lack of resources, they are hindered in internationalization compared to large firms [35, 68]. So, for small business, resources-based veiw has not provided effective solutions. Export marketing 
research has focused too much on large firms [26]. Despite the increasing role of small firms in the world economy, very few studies have examined emerging-market firms [37, $48]$ and research for small firms are still embryonic [15, 31, 35, 43, 48, 55, 59]. There has been very little research on how small entrepreneurs can overcome these deficiencies.

The aim of this paper is to explain how small firms in emerging markets adopts EMS in CBEC with their limited resources. To fill the research gap between existing literatures which focus on large firms, we employed recent findings from extant research. Recent studies have suggested that emerging-market firms can overcome their constrained resources by leveraging other capabilities [35]. Small business relies on entrepreneurs' capabilities [64, 95]. Also, they mobilize external partners' resources, and apply existing resources in multiple roles. So, we adopted research on dynamic managerial capabilities (DMCs), which explains variations in entrepreneurs' capabilities, including entrepreneurs cognitive and networking capabilities [5, 45]. Also, we adopted the concept of resource versatility which means multiple use of existing resources.

We adopted qualitative research methods and chose business cases in Mongolia. In Mongolia, there is growing needs of CBEC for them due to its domestic market constraints. Theoretically, this research deal with boundary conditions of existing theories and present better explanations or small firms in emerging market. With interview and discussion with entrepreneurs and business incubation center, this study come up with practical strategies for small firms in Mongolia. This would be useful findings for other emerging market small businesses. It is timely, since due to the current global pandemic, small firms need to strengthen their CBEC.

\section{Literature Review}

\subsection{International Marketing Capability}

Firms mobilize their internal resources to adopt EMS $[46,47,54]$ and achieve competitive advantage $[7,8,77]$. Their internal resources, such as a firm's management commitment, firm experience, and product uniqueness have proven to have positive impacts on EMS [47, 54]. In terms of management commitment, highly committed managers are likely to proactively adopt EMS $[62,105]$. For firm experience, more experienced firms better identify market demands and possess understanding of foreign markets [54]. Also, product uniqueness - the degree to which a product incorporates features to satisfy consumers' unique needs [17] - helps firms gain competitive advantage in foreign markets [67]. (See Figure 1 for the conceptual framework of EMS.)

However, Smalll firms face lack of internal resources to come up with EMS compared to larger entities. Due to resource constraints, small firms are at a disadvantage compared to large firms [68]. For management commitment, they are not convinced of the value of e-commerce [85]. In terms of firm experiece, they have a low level of marketing experience $[51,103]$. Thus, it is harder for them to expand beyond their domestic market [51, 103] or plan for internationalization [86]. 


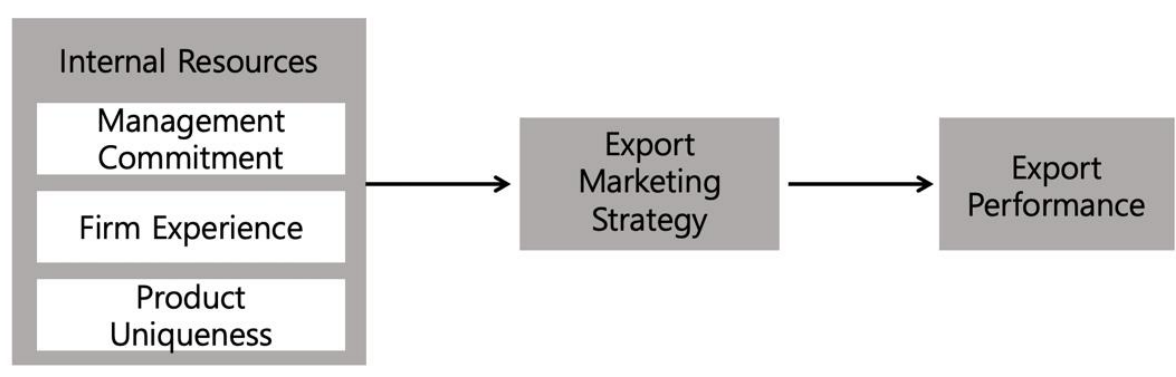

Figure 1. Internal determinants of EMS [44].

\section{2. Need of Dynamism in Marketing Capabilities}

Small business takes measures to mitigate the constraints upon them [14, 36, 73]. However, internal-resource-based view has been criticized as being static [82, 95]. Not fixed resources, but dynamic capabilities have positive impatcs on in CBEC [35, 42, 89] and firm performance $[93,95]$. Although firms' capabilities are derived from internal resources, they are not just sum of internal resources [3, 7, 44, 95]. Capabilities are bundles of skills and knowledge that firms make use of their resources [29].

Therefore, we applied the concept of international dynamic marketing capability (IDMC), which explains how firms purposefully integrate, build, and modify internal and external resources $[72,94,95]$. For example, export-oriented capabilities including marketing capability [58], networking capability [76], and internationalization capability [80] enhance foreign market performance [4].

There are key dynamic maketing capabilities that small business make use of. These are distinguished from internal resources of large firms. First, most small firms are managed by a single owner $[53,91]$. Small business relies heavily on the entrepreneur's capabilities compared to large firms $[64,95]$. To assess this characteristic, we adopted research on dynamic managerial capabilities (DMCs), which explains variations in entrepreneurs' capabilities [5, 45]. DMC provides a useful theoretical lens to assess this. Second, small firms also incorporate external partners' capabilities to extend their resource bases, not just mobilize capabilities from existing resources [34, 93, 94]. DMC also entails collaboration with external partners [5, 45]. Because DMCs well explains this dynamism, it has gained popularity in recent years [9]. Thirdly, small firms are more cross-functional than large firms. It modifies the certain capabilities and use them in many ways. Certain capabilities are applied in multiple roles. This makes the existing resources more versatile [78], so we adopted research on resource versatility [78]. More detailed explanations on how we incorporated extant research is following.

\subsection{Entrepreneurs' Dynamic Capability}

Managerial capability is how managers build, integrate, and reconfigure their organizational resources [2]. It includes managerial cognition; their personal beliefs and mental models for decision-making [2,49]. This affects how the firm sense market changes and thusm affects subsequent behavior. For example, firms with inert managerial cognition fail to recognize the market changes and fail to achive high performace [49], while entrepreneurs' capabilities to be proactive in seeking new markets impacts their adoption of 
EMS resulting better export performance [70]. Entrepreneurial orientation refers to the ability to be proactive in seeking new markets $[66,101]$. Strong entrepreneurial orientation leads to the development of EMS $[35,56]$.

Hence, we propose the following: Proposition 1. Entrepreneurial orientation is a prerequisite for small companies to develop EMS.

\subsection{Networking Capability}

Network is interconnected firms and managers involved in economic activities that convert resources into outputs $[22,88]$. It also includes external agents, such as technological alliance partners [36, 50,59] and even informal relationships [52]. Firms leverage networks to obtain competitive advantages and achieve business goals [4]. Network enables firms to renew resources and develop marketing capabilities and marketing strategies [35, 61, 67]. In exporting, network is also important. For example, external partners perform even core activities, including export marketing [35]. and local partners identify new market opportunities [81].

Small business use network capabilities continually to reinforce their own capabilities [87]. Especially in the early stage of internationalization, they leverage external partners' capabilities [23,36,38] and sense market opportunities [1]. Entrepreneur's network capability makes up for the firm's lack of resources [10] and determines the firm's network [79]. Entrepreneur's network helps a firm to obtain and reconfigure resources [49, 97]. In this way, entrepreneur's formal and informal networks and networking activities function as marketing [49, 59, 61] and lead to better marketing strategies [35].

Hence, we claim the following: Proposition 2 . The networking capability of entrepreneurs has a positive impact on EMS.

\subsection{Versatile Dynamic Capability}

Constrained by the scarcity of resources, small businesses need to use existing resources effectively. Often, they modify certain capabilities and use them in multiple roles [12]. For example, capabilities in marketing and product development overlap [73]. Resource versatility conceptualizes how certain resources support multiple roles in resourceconstrained firms [78].

Hence, we claim the following: Proposition 3. Versatile dynamic capabilities have a positive impact on EMS.

To summarize, Figure 2 explains the international dynamic marketing capabilities (IDMCs) of emerging-market small firms. Based on recent findings in managerial dynamic capability theory and resource versatility, these are are different from the internal resources of large firms. For small business, entrepreneurial orientation, networking capability, and versatile dynamic capability are more relevant than restrained internal resources. More specifically, entrepreneurs' dynamic capabilities and the effective use of existing capabilities lead to better EMS and export performance. 


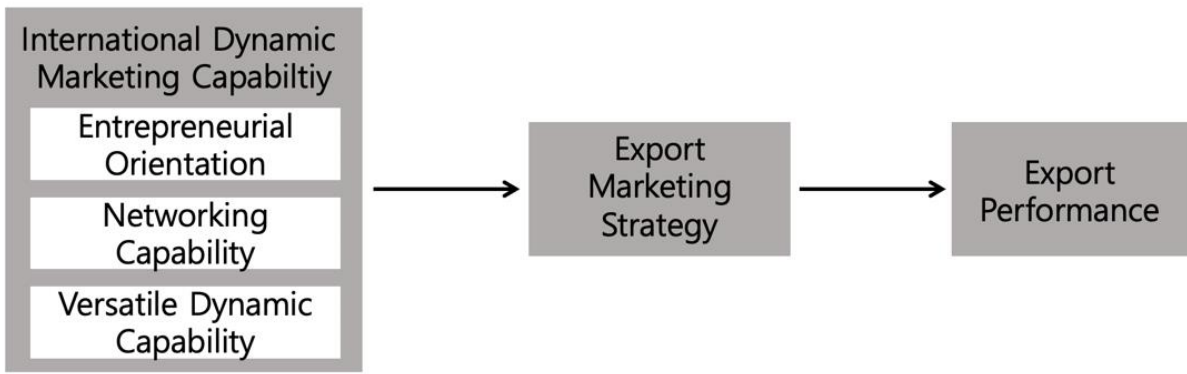

Figure 2. International dynamic marketing capabilities(IDMC) of emerging-market small business

\section{Research Methods}

\subsection{Research Design}

The aim of this study is to explore how small businesses in emerging economy adopts EMS in CBEC. We adopted qualitative study methods to derive findings from under-studied phenomena [33], and to understand processes that could not be disassociated from their context $[11,13,30,57]$. This is to compare new empirical findings with those of prior studies [77].

\subsection{Data Collection}

For case analysis, we selected small business in Mongolia for several reasons. First, Mongolia is an emerging economy with growing e-commerce. Its domestic e-commerce industry shows unprecedented growth; its revenue increased more than $60 \%$ during 2020 [39]. It also has relatively good infrastructure for e-commerce in the capital city, Ulaanbaatar. Of the country's total population of 3 million, 2.6 million have internet access, 2 million use smartphones, and 1.3 million use social networking services (SNSs) on a regular basis [39]. All these show its potential for CBEC. Also, CBEC is necessary for Mongolia to overcome the challenging geography of the country.

However, Mongolian small firms have relatively little of the technology and the skilled human capital resources necessary for CBEC. Thus, there are demands from them to improve their export with constrained resources. So, international non-governmental organizations (INGOs) and governments are currently supporting small business entrepreneurs to export to foreign markets. One of the best examaple is Ulaanbaatar the Women's Business Center (WBC). It was established in 2016 to support female entrepreneurs in Mongolia. The Asia Foundation (INGO), Mongolian government, and Korean government (Korea International Cooperation Agency; KOICA) cooperate to incubate Mongolian entrepreneurs and to support their e-commerce, including CBEC.

We collected data from multiple sources for triangulation [33]. With the support from The Asia Foundation, we could implement internal documents reviews, interviews, site visits, and focus-group discussions with many relevant parties. We visited Ulaanbaatar and interviewed entrepreneurs. To select representative small businesses, the following criteria were applied: the business (a) had to be located in the WBC service area; (b) had to have fewer than 15 employees; (c) had to have experience in generating revenue in 
domestic e-commerce; (d) had to be currently doing or planning to do CBEC; and (e) had to be selected by a support organization as having potential for exporting.

To enhance feasibility and practicability of the resaerch, we also interviewed with external partners of small business in Ulaanbaatar, including The Asia Foundation Mongolia office, IT service firms, and banks. To ensure the resaerch findings, we also interviewed people who have experience in exporting Mongolian goods to Korea. We selected five interviewees from small businesses and seven from external partners. Table 1 shows the details of the interviews.

Table 1. Information about the Interviews

\begin{tabular}{ccccc}
\hline Case & Interviewee & Nationality & Role & Interview Occasion \\
\hline A & Entrepreneur & Mongolia & Eco-friendly flowerpots & Sep 9, 2019 / Ulaanbaatar \\
\hline B & Entrepreneur & Mongolia & Organic foods and beverages & Sep 9, 2019 / Ulaanbaatar \\
\hline C & Entrepreneur & Mongolia & Hand-crafted goods & Sep 9, 2019 / Ulaanbaatar \\
\hline D & Entrepreneur & Korea & IT center in Ulaanbaatar & Aug 16, 2019 / Seoul \\
\hline E & Manager & Mongolia & IT center in Ulaanbaatar & Sep 10, 2019 / Ulaanbaatar \\
\hline F & Head of corporate sales & Mongolia & Digital finance service & Sep 10, 2019 / Ulaanbaatar \\
\hline G & CEO & Mongolia & Bank (Former) & Sep 10, 2019 / Ulaanbaatar \\
\hline H & Country Representative & US & INGO in Korea & July 18, 2019 / Seoul \\
\hline I & Manager & US & INGO in Mongolia & Aug 27, 2019 / Seoul \\
\hline J & Manager & Mongolia & INGO in Mongolia & Sep 9, 2019 / Ulaanbaatar \\
\hline K & Manager & Mongolia & INGO in Mongolia & Sep 9, 2019 / Ulaanbaatar \\
\hline L & Manager & Korea & Korea government (Former) & June 26, 2020 / Seoul \\
\hline M & Manager & US & INGO in Mongolia & Sep 20, 2019 / Washington D.C. \\
\hline
\end{tabular}

At each interview, entrepreneurs were encouraged to speak freely with no forced answers. The interviews were conducted in Mongolian, Korean and English and the average length was about one hour. With entrepreneurs, we tried to understand how small firms adopts CBEC and EMS. For external partners, we tried to confirm how they understand the process of small firms exporting through e-commerce. After the compeletion of the research, we againg contacted external partners, especaially experienced staffs of the supporting ornazation to check their views on feasibilities and possible applications of research findings to real business cases, based on their experience. They check the validity of our research findings, and several findings were actually adopted by INGO to effectively support small business entrepreneurs' CEBC.

\subsection{Data Analysis}

For data analysis, we described the interview results and identified how the interviewees' experience and opinions relate to the research framework. Two researchers repeatedly reviewed the interview results and reach the consensus [98]. This analysis was similar to the Strauss and Corbin's notion of open coding [40]. Then the results were grouped into first-order categories. We shifted back and forth between the findings and the broad scope of literatures to identify the findings that theoretically supported the consensus (second-order constructs). 
For example, interview results were first labeled as "lack of firm experience." Thereafter, relevant theoretical constructs and responses, which can replace internal resources, were classified in suitable categories according to theories. For example, entrepreneurs' ten to rely on his/her own networks for export, and external partners also agree that small business can get better export result with network capaibility. After all, that was integrated into theoretical construct, networking capability. The consensus and findings were reported back to support organizations to ensure their practicality and validity. The level of disagreement was generally low. Through these processes, we tried to match the data with existing theories [40]. Figure 3 explains the data structure and research findings.

\begin{tabular}{|c|c|c|}
\hline Descriptions from interviews and literatures & Solutions from interviews and literatures & Constructs \\
\hline $\begin{array}{l}\text { - Entrepreneurs lack commitment on CBEC } \\
\text { - Entrepreneurs want to expand business to } \\
\text { foreign markets } \\
\text { - INGO supports growth of small business }\end{array}$ & $\begin{array}{l}\text { - Export is critical to overcome } \\
\text { domestic market constraints } \\
\text { Entrepreneurs need supports on } \\
\text { export }\end{array}$ & $\begin{array}{c}\text { Entrepreneurial } \\
\text { Orientation }\end{array}$ \\
\hline $\begin{array}{l}\text { - Entrepreneurs lack experience in CBEC } \\
\text { Entrepreneurs lack resources to set up } \\
\text { Independent e-commerce website } \\
\text { - Complex legal and administrative } \\
\text { procedures in foreign market } \\
\text { - Entrepreneurs deal with deliversy service } \\
\text { individually }\end{array}$ & $\begin{array}{l}\text { - Third-party digital platforms } \\
\text { reduces costs and risks } \\
\text { - Exporter services reduce costs and } \\
\text { risks } \\
\text { - INGO supports collective contracts }\end{array}$ & $\begin{array}{l}\text { Networking } \\
\text { Capability }\end{array}$ \\
\hline $\begin{array}{l}\text { - Entrepreneurs lack product uniqueness } \\
\text { - Marketing capabilities can supplement } \\
\text { product uniqueness } \\
\text { - Digital marketing is effective and efficient }\end{array}$ & $\begin{array}{l}\text { - INGO supports collective branding } \\
\text { - Entrepreneurs use SNS } \\
\text { - Entrepreneurs need supports on } \\
\text { digital marketing }\end{array}$ & $\begin{array}{l}\text { Versatile } \\
\text { Dynamic } \\
\text { Capability }\end{array}$ \\
\hline
\end{tabular}

Figure 3. Data structure.

\section{Case Findings}

\subsection{From "Managerial Commitment" to "Entrepreneurial Orientation"}

Entrepreneurial orientation can be facilitated for EMS [35], so this might lead Mongolian entrepreneurs to adopt EMS for better export performance. According to the interviews, most of the entrepreneurs were not commited enough to CBEC. Although they had experience in domestic e-commerce, cross-border presents unprecented challenges since it entails export procedures, including customs and cross-border deliveries that they are not accustomed to. However, they want to enter foreign markets to expand their business. All in all, despite low level of commitment, small business entrepreneurs had entrepreneurial orientation:

"I want to export the product to abroad. [...] However, I never experienced selling products abroad [...]. It is difficult for me to know about export procedures [...] It is hard to get necessary information regarding export [...] It is challenging for us [...] We hope we can get support." (Entrepreneur, Respondent A)

"We are currently selling organic juice essence to Japan [...] We also want to expand to [the] Korea market. Export entail taxes, deliveries and other complex procedures [...]" (Entrepreneur, Respondent B)

"We plan to sell hand-crafted goods to foreign markets [...] We need to check whether it is possible or not [...] We need consultations on this [...]" (Entrepreneur, Respondent C) 
We found that managers from external partners (INGO, Bank, Financial service provider, and government) consider cross-border e-commerce is a critical factor for the growth of small business. Support organizations explained how they facilitate this entrepreneurial orientation by sharing other entrepreneurs' success. They shared their strategic views:

"We want micro-entrepreneurs from developing countries to sell their products abroad, since their [local] market size, including Mongolia, has clear limitations for growth of the companies [...] Also, export through e-commerce opens windows of opportunities for them [...] The e-commerce market cannot be ignored, since most transactions are now moving to e-commerce [...] so we are putting our effort to find effective strategies to support export using e-commerce." (Country Representative of INGO, Respondent H)

"We are building up e-commerce websites which sell small business products [...] We can offer digital platforms for micro-entrepreneurs to sell their products [...] Not just production - we want to support selling products." (Manager of INGO, Respondent I)

"We are planning to design programs for entrepreneurs based on their needs ... such as sharing [the] experience of other successful exporters [...] Once we invited entrepreneurs from Korea to share their experiences in exporting [...] Through those experiences, entrepreneurs were motivated about export." (Manager of INGO, Respondent J)

\subsection{From "Firm Experience" to "Networking Capability"}

Due to the lack of firm experience, small businesses are confronted with many challenges. The small firms we interviewed expressed their concerns about their lack of knowledge and experience:

"In the domestic market, most of our products are sold online [...] Facebook is the most frequent channel for selling online [...] However, I concerned that I never experienced selling products abroad." (Entrepreneur, Respondent A)

One of the main challenges small businesses facing is adoption of a digital platform for CBEC. Large companies develop their own digital platforms [19, 28]. However, it takes a lot of resources for small firms to set up their own digital platforms. Instead of making investments to set up own website, small firms can utilize existing third-party platforms [99]. Third-party digital platforms provide easy access to international markets [24], and help small businesses take advantage of existing industrial chains, trade processes, payment methods, logistics, and warehousing [104]. They also help reduce risks and transaction costs with existing trust to the platform [90]. Small firms can rely on third-party digital platforms [6] such as Amazon and Alibaba, which provide small exporters with technological tools to analyze customers [100], payments, and even logistics services [74].

To validate these findings in the Mongolia context, we analyzed concrete options for Mongolian entrepreneurs to export their products to the Korean market. First option, setting up their own independent web platforms, legal and administrative procedures, including business registration and e-commerce registration in Korea, are required. However, using third-party platforms for CBEC, such as G-market Global Shop (Korean ecommerce platform), does not require this process. This open-market platform aims to provide services to less-resourced independent sellers. IT service provider in Mongolia 
also agrees this finding based on their experience. We discussed this result with the INGO which support CBEC of small business and concluded that using existing digital platform, rather than setting up their own is better option:

"We recommend using Korea open market services [...] We do not recommend making an independent website [...] Because micro-enterprises do not have the expertise, experience, or enough resources to set up and manage a digital platform [...] They might face difficulties in managing it." (Entrepreneur, Respondent D)

"So far, we have put our budget on setting up independent websites for entrepreneurs [...] However, according to the analysis, it seems that we should rather focus on supporting entrepreneurs entering into existing market platforms [...] It will save lots of financial resources [...] It will be more practical and effective [...]" (Manager of INGO, Respondent I)

Another case for small firms to use network capability is exporter service. Exporter services include deliveries, customs, and administrative procedures. While export is challenging procedures for small business, it can be outsourced to specialzed and experience agencies [90]. Outsourcing improves the service, reduces costs, and enables entrepreneurs to focus on their core business [63]. Currently interviewed entrepreneurs deal with export procedures individually. However, after interviews and discussions we suggested that small business could make a collective to use exporter services, such as making contract with multiple small firms with distributors. The possibility of this suggestion was confirmed by experienced exporter. For example, the Korean government agency provides collective delivery services for Korean SME products:

"It is plausible to use delivery services collectively [...] There is an existing logistic service exporting Mongolian products to Korea run by exporter company [...] Usually, they make contract with big exporting companies [...] Likewise, Mongolian entrepreneurs can cooperate with each other and make contract with them collectively." (Entrepreneur, Respondent D)

In this way, support organizations can foster partnerships between exporters and multiple small firms. In fact, this strategy is already implemented in advanced countries. In Korea, a government agency now provides collective delivery services for Korean small and mid-size enterprise (SME) products.

\subsection{Versatile Dynamic Capability}

For small businesses, satisfying the unique needs of customers in foreign markets is challenging. Withought differentiated products with competitiveness, it is hard to persuade foreign consumers to buy the product. Mongolian products are also challenged by this. Entrepreneur who has experience in exporting Mongolian products to Korea for many years shared his view that in several categories, there are posibilities of competitive edge. It seems that only few product categories have product uniqueness, and many others face challenges regarding product uniqueness:

"Mongolian products with cheap prices are competing with Chinese products in foreign markets [...] In many cases, it is challenging to have a competitive advantage [...] Rather than cheap products, there are several categories that have competitiveness in foreign markets [...] For example, natural ingredients such as honey [...] Several products made from natural ingredients have high quality and good perception in Korea [...] Also cashmere have a competitive 
edge in Korea market [...] However, they have other challenges such as food standards [...] producer associations who deter imports in foreign countries [...] In Korea, selling Mongolian honey was tried several times, but faced challenges." (Entrepreneur, Respondent D)

"Products which are exported to nearby markets, including Korea, China, and Japan, are cashmere, wool, yak, frozen meat, salt... They are cheap and high quality [...] and so have competitiveness." (Manager of INGO, Respondent I)

For small business, this challenge is much more critical obstacle for them to export to foreign markets. However, according to the resource versatility, product uniqueness can be supplemented with marketing capabilities. Innovative marketing enables small firms to differentiate their products [79]. For example, branding, which entails names, signs, symbols, or designs, differentiates the products in export markets [63].

Therefore, we suggest that smalll business can gather and collectively form branding strategy. This collective branding might supplement product uniqueness. For example, rather than individual small brands, collective brand such "Mongolian Natural Cashmere Initiative" can be formed with entrepreneurs and supporting organizations. Such strategies are already implemented in similar cases supported by international organizations such as the United Nations Development Programme (UNDP) and (WIPO) for the purpose of supporting local producers. In this case, these supporting organizations are actively engaged as guaranteers of product quality. Along with this, collective efforts such contracting with local marketing agencies is suggested:

"I think collective branding can be a good solution for entrepreneurs [...] In cases of social enterprises in the US or europe, they are supported by certifications or collective brading from external supporters [...] Consumers are convinced of quality of products." (Former manager of INGO, Respondent $M$ )

"Products which are exported to nearby markets, including Korea, China, and Japan, are cashmere, wool, yak, frozen meat, salt... They are cheap and high quality [...] and so have competitiveness." (Manager of INGO, Respondent I)

"Collective effort would be more effective and efficient [...] Collectively contracting with Korean marketing agencies is required, rather than contracting individually." (Manager of government, Respondent L)

In addition to this, digital marketing, especially social media, enables word-of-mouth communication and increases sales [21]. With small budgets, innovative communication can be employed [71, 83, 91]. Small firms use less-resource-intensive open-source solutions [60, 71, 92]., such as SNS [28] and search engine advertisements [42]. Digital marketing clearly leads to better export performance [18, 46, 91], since it helps to build longlasting customer relationships [48]. According to interviews, entrepreneurs use SNSs as digital marketing tools. Thus, it is effective to support entrepreneurs to be equipped with digital marketing capabilities. According to interviews both entrepreneurs and supporting organizations expressed their needs on capacity building regarding digital marketing tools:

"We get orders and feedbacks using Facebook [...] It is the most convenient way of doing ecommerce with little expense." (Entrepreneur, Respondent $A$ ) 
"We need to understand the Korean language and culture to export [...] Even specific skills such as PhotoShop and SNS marketing do help." (Entrepreneur, Respondent C)

"How to implement online marketing would be helpful." (Entrepreneur, Respondent B)

"Entrepreneurs like practical workshops regarding SNS [...] For example, simple skills such as taking photos and uploading them to an SNS with a basic design helps them a lot in ecommerce." M (Manager of INGO, Respondent K)

\section{Discussion}

Based on resource-based view, internal determinants of EMS are management commitment, firm experience, and product uniqueness. However, small business lack resources and this perspective is static and does not consider dynamism in small business. So, this resource-based view does not apply to small firms from emerging economies which are doing critical role in economy of developing countries.

To add dynamism in understanding how small firms adopts EMC, we adopted findings from extant research. Dynamic managerial capabilities explain entrepreneurs' various capabilities and network capabilities which invites external partners capabilities enhance the small firms' own capabilities. For small firms, which rely heavily on entrepreneurs' role and network, this reflects realities of adopt of EMS for small business. External parties' capabilities can supplement firms' lack of resources. Also, rather than product uniqueness, which small firms lack in many cases, capability which are versatile to a broad range of service is more adequate to explain marketing of small firms. Resource versatility explains how limited resources can be effectively utilized capabilities for multiple functions. For small firms, they can use collective branding and digital marketing capabilities effectively to compensate product uniqueness with restricted resources.

By merging findings from multiple data sources, including interviews with entrepreneurs and support organizations, this paper confirmed research findings regarding new components of determining factors of EMS for small firms. It replaces the existing internal determinants of EMS with new components: entrepreneurial orientation, networking capability, and versatile dynamic capabilities. In terms of entrepreneurial orientation, Mongolian entrepreneurs are motivated to enter the Korean market. Networking capability enables Mongolian entrepreneurs to use third-party marketplaces rather than develop their own independent websites. Rather than focusing on their products' uniqueness, they can adopt collective branding strategies and use less-resource-consuming digital marketing tools to complement their products' uniqueness. Those factors have proven be more adequate to explain export marketing of small companies both in literatures and busienss cases in Mongolia.

\section{Conclusions}

Theoretically, this study presents a fresh point of view on how small business adopts export marketing strategies. It needs a procedural approach with dynamism rather than a static approach based on resourced-based view. Scholars have specifically called for research applying the effectuation theory to further our understanding about the topic [53] and the dynamic marketing capabilities concept [73]. Whereas previous research often 
treated "capability" as static, our study shows how small businesses can mobilize entrepreneurs' external resources and multiple uses of limited resources. This versatility approach well explains that certain characteristics of all small firms, like flexibility and fast learning, can be leveraged. This approach is a meaningful in terms of responding to those requests from previous studies.

The results of this research are also valuable in practical terms for developing countries. While support organizations seek effective ways to enhance exports, they should not approach small businesses with static, resource-based views. Current policy prescriptions often focus on the creation of property-based resources in the form of patents and technical skills [102]. However, they need to facilitate small businesses by connecting them with cross-border partners' capabilities [41]. Small firms can learn through their interactions with foreign customers, and they can work well with e-commerce platforms, thirdparty logistics services, and local marketing agencies.

There are several limitations to this study. First, our examination was conducted in the unique economic context of Mongolia and Korea. Also, data was collected only from the capital city of Mongolia, which may not represent the whole country's population. Secondly, we relied on interviews with a relatively small number of informants. Even though we tried to enhance the interview data with support organizations that have rich experience with small businesses, we have limited number of business cases. Third, as a related aspect, the concept of external partnerships raises concerns regarding control and power issues between the focal firm and its partners [81]. Finally, we focused on the capability perspective, which does not address many other aspects, such as organizational structure and routines.

Future studies could be extended to more diversified group of entrepreneurs, such as rural producers, other countries, and other markets, which would provide the possibility for comparison with the role of IDMC in small businessesr operating in other markets. The collection of additional case studies and survey data would enhance the generalizability of the results. Also, to confirm each determinant, quantitative research is needed.

Author Contributions: Conceptualization, K.K.; methodology, K.K.; validation, K.K. and G.L.; formal analysis, K.K.; investigation, K.K. and G.L.; resources, K.K. and G.L.; data curation, K.K. and G.L.; writing-original draft preparation, K.K.; writing-review and editing, K.K.; visualization, K.K.; supervision, G.L.; project administration, K.K.; funding acquisition, K.K. and G.L. All authors have read and agreed to the published version of the manuscript.

Funding: This research was partly supported by The Asia Foundation. This work was supported by the research fund of Hanyang University(HY-201800000001046).

Acknowledgments: The authors would like to thank the anonymous reviewers for their insightful comments and remarks which enabled correcting the article. Special thanks to the interviewed experts, especially from The Asia Foundation's Korea and Mongolia offices.

Conflicts of Interest: The authors have no conflicts of interest to declare. 


\section{References}

1. ADLER, Paul S.; KWON, Seok-Woo. Social capital: Prospects for a new concept. Academy of management review, 2002, 27.1: 1740.

2. Adner, R.; HELFAT, C. E. Corporate effects and dynamic managerial capabilities. Strategic management journal, 2003, 24.10: 1011-1025.

3. Al-Aali, A.; TEECE, David J. International entrepreneurship and the theory of the (Long-Lived) international firm: a capabilities perspective. Entrepreneurship Theory and Practice, 2014, 38.1: 95-116.

4. Andersen, O. Internationalization and market entry mode: A review of theories and conceptual frameworks. MIR: Management International Review, 1997, 27-42.

5. Bahl, M.; Lahiri, S.; \& Mukherjee, D. Managing internationalization and innovation tradeoffs in entrepreneurial firms: Evidence from transition economies. Journal of World Business, 2021, 56(1), 101150.

6. Banerjee, P. K.; Ma, L. C. Routinisation of B2B E-commerce by small firms: A process perspective. Information Systems Frontiers, 2012, 14(5), 1033-1046.

7. Barney, J. Firm resources and sustained competitive advantage. Journal of management, 1991, 17(1), 99-120.

8. Barney, J. B. Strategic factor markets: Expectations, luck, and business strategy. Management science, 1986, 32(10), $1231-1241$.

9. Barrales-Molina, V.; Martínez-López, F. J.; Gázquez-Abad, J. C. Dynamic marketing capabilities: Toward an integrative framework. International Journal of Management Reviews, 2014, 16(4), 397-416.

10. Blesa, A.; Ripolles, M. The influence of marketing capabilities on economic international performance. International Marketing Review. 2008

11. Bluhm, D. J.; Harman, W.; Lee, T. W.; Mitchell, T. R. Qualitative research in management: A decade of progress. Journal of Management Studies, 2011, 48(8), 1866-1891.

12. Bocconcelli, R.; Cioppi, M.; Fortezza, F.; Francioni, B.; Pagano, A.; Savelli, E.; Splendiani, S. SMEs and marketing: a systematic literature review. International Journal of Management Reviews, 2018, 20(2), 227-254.

13. Bonoma, T. V. Case research in marketing: opportunities, problems, and a process. Journal of marketing research, 1985, 22(2), 199-208.

14. Buccieri, D.; Javalgi, R. G.; Cavusgil, E. International new venture performance: Role of international entrepreneurial culture, ambidextrous innovation, and dynamic marketing capabilities. International Business Review, 2020, 29(2), 101639.

15. Caputo, A.; Pellegrini, M. M.; Dabic, M.; Dana, L. P. Internationalisation of firms from Central and Eastern Europe: A systematic literature review. European business review, 2016

16. Cassia, F.; Magno, F. Cross-border e-commerce as a foreign market entry mode among SMEs: the relationship between export capabilities and performance. Review of International Business and Strategy. 2021

17. Cavusgil, S. T.; Zou, S.; Naidu, G. M. Product and promotion adaptation in export ventures: an empirical investigation. Journal of International Business Studies, 1993, 24(3), 479-506.

18. Chaffey, D.; Ellis-Chadwick, F. Digital marketing. 2019, Pearson uk.

19. Chen, J. E., Pan, S. L., \& Ouyang, T. H. (2014). Routine reconfiguration in traditional companies'e-commerce strategy implementation: A trajectory perspective. Information \& Management, 51(2), 270-282.

20. Chen, J.; Sousa, C. M.; Xinming, H. The determinants of export performance: a review of the literature 2006-2014. International marketing review., 2016, 33(5), 626-670.

21. Chen, Y.; Fay, S.; Wang, Q. The role of marketing in social media: How online consumer reviews evolve. Journal of interactive marketing, 2011, 25(2), 85-94. 
22. Chetty, S.; Agndal, H. Social capital and its influence on changes in internationalization mode among small and mediumsized enterprises. Journal of International Marketing, 2007, 15(1), 1-29.

23. Chetty, S.; Ojala, A.; Leppäaho, T. Effectuation and foreign market entry of entrepreneurial firms. European Journal of Marketing. 2015

24. Church, E. M.; Oakley, R. L. Etsy and the long-tail: how microenterprises use hyper-differentiation in online handicraft marketplaces. Electronic Commerce Research, 2018, 18(4), 883-898.

25. Cieślik, J.; Kaciak, E.; Thongpapanl, N. T. Effect of export experience and market scope strategy on export performance: Evidence from Poland. International Business Review, 2015, 24(5), 772-780.

26. Colton, D. A.; Roth, M. S.; Bearden, W. O. Drivers of international e-tail performance: the complexities of orientations and resources. Journal of International Marketing, 2010, 18(1), 1-22.

27. Corbin, J.; Strauss, A. Basics of qualitative research: Techniques and procedures for developing grounded theory. Sage publications, 2014

28. Cui, M.; Pan, S. L. Developing focal capabilities for e-commerce adoption: A resource orchestration perspective. Information $\mathcal{E}$ Management, 2015, 52(2), 200-209.

29. Day, G. S. The capabilities of market-driven organizations. Journal of marketing, 1994, 58(4), 37-52.

30. De Cock, R.; Andries, P.; Clarysse, B. How founder characteristics imprint ventures' internationalization processes: The role of international experience and cognitive beliefs. Journal of World Business, 2021, 56(3), 101163.

31. Dikova, D.; Jaklič, A.; Burger, A.; Kunčič, A. What is beneficial for first-time SME-exporters from a transition economy: A diversified or a focused export-strategy?. Journal of World Business, 2016, 51(2), 185-199.

32. Eggers, F.; Hatak, I.; Kraus, S.; Niemand, T. Technologies that support marketing and market development in SMEsEvidence from social networks. Journal of Small Business Management, 2017, 55(2), 270-302.

33. Eisenhardt, K. M. Building theories from case study research. Academy of management review, 1989, 14(4), 532-550.

34. Fainshmidt, S.; Pezeshkan, A.; Lance Frazier, M.; Nair, A.; \& Markowski, E. Dynamic capabilities and organizational performance: a meta-analytic evaluation and extension. Journal of Management Studies, 2016, 53(8), 1348-1380.

35. Falahat, M.; Knight, G.; Alon, I. Orientations and capabilities of born global firms from emerging markets. International Marketing Review. 2018

36. Fang, E. E.; Zou, S. Antecedents and consequences of marketing dynamic capabilities in international joint ventures. Journal of International Business Studies, 2009, 40(5), 742-761.

37. Felzensztein, C.; Ciravegna, L.; Robson, P.; Amorós, J. E. Networks, entrepreneurial orientation, and internationalization scope: evidence from Chilean small and medium enterprises. Journal of Small Business Management, 2015, 53, $145-160$.

38. Galkina, T.; Chetty, S. Effectuation and networking of internationalizing SMEs. Management International Review, 2015, 55(5), 647-676.

39. Gantulga, U.; Sampil, B.; Davaatseren, A. Analysis of E-Commerce Adoption in Ulaanbaatar, Mongolia. Trade Research, 2021, 17, 67-80.

40. Gioia, D. A.; Corley, K. G.; Hamilton, A. L. Seeking qualitative rigor in inductive research: Notes on the Gioia methodology. Organizational research methods, 2013, 16(1), 15-31.

41. Gnizy, I. The role of inter-firm dispersion of international marketing capabilities in marketing strategy and business outcomes. Journal of Business Research, 2019, 105, 214-226.

42. Goldman, S.; van Herk, H.; Verhagen, T.; Weltevreden, J. VU Research Portal. 2020

43. Gonzalez-Perez, M. A.; Manotas, E. C.; Ciravegna, L. International SMEs from emerging markets - Insights from the Colombian textile and apparel industry. Journal of International Entrepreneurship, 2016, 14(1), 9-31.

44. Grant, R. M. The resource-based theory of competitive advantage: implications for strategy formulation. California management review, 1991, 33(3), 114-135. 
45. Graves, C.; Thomas, J. Internationalization of Australian family businesses: A managerial capabilities perspective. Family business review, 2006, 19(3), 207-224.

46. Gregory, G. D.; Ngo, L. V.; Karavdic, M. Developing e-commerce marketing capabilities and efficiencies for enhanced performance in business-to-business export ventures. Industrial Marketing Management, 2019, 78, 146-157.

47. Gregory, G.; Karavdic, M.; Zou, S. The effects of e-commerce drivers on EMS. Journal of International Marketing, 2007, 15(2), 30-57.

48. Hagen, B.; Zucchella, A.; Ghauri, P. N. From fragile to agile: marketing as a key driver of entrepreneurial internationalization. International Marketing Review. 2019

49. Helfat, C. E.; Martin, J. A. Dynamic managerial capabilities: Review and assessment of managerial impact on strategic change. Journal of management, 2015, 41(5), 1281-1312.

50. Hou, J. J.; Chien, Y. T. The effect of market knowledge management competence on business performance: A dynamic capabilities perspective. International Journal of Electronic Business Management, 8(2). 2010

51. Javalgi, R. R. G.; Todd, P. R. Entrepreneurial orientation, management commitment, and human capital: The internationalization of SMEs in India. Journal of Business Research, 2011, 64(9), 1004-1010.

52. Jones, M. V.; Coviello, N. E. Internationalisation: conceptualising an entrepreneurial process of behaviour in time. Journal of international business studies, 2005, 36(3), 284-303.

53. Jones, R.; Rowley, J. Entrepreneurial marketing in small businesses: A conceptual exploration. International small business journal, 2011, 29(1), 25-36.

54. Karavdic, M.; Gregory, G. Integrating e-commerce into existing export marketing theories: A contingency model. Marketing Theory, 2005, 5(1), 75-104.

55. Kiss, A. N.; Danis, W. M.; Cavusgil, S. T. International entrepreneurship research in emerging economies: A critical review and research agenda. Journal of Business Venturing, 2012, 27(2), 266-290.

56. Knight, G. Entrepreneurship and marketing strategy: The SME under globalization. Journal of international marketing, 2000, $8(2), 12-32$.

57. Knight, G. A.; Cavusgil, S. T. Innovation, organizational capabilities, and the born-global firm. Journal of international business studies, 2004, 35(2), 124-141.

58. Kotabe, M.; Srinivasan, S. S.; Aulakh, P. S. Multinationality and firm performance: The moderating role of R\&D and marketing capabilities. Journal of international business studies, 2002, 33(1), 79-97.

59. Kowalik, I.; Danik, L.; Francioni, B. Specialized marketing capabilities and foreign expansion of the international new ventures. Journal of Small Business Management, 2020, 1-39.

60. Kraus, D.; Reibenspiess, V.; Eckhardt, A. How voice can change customer satisfaction: a comparative analysis between ecommerce and voice commerce. 2019

61. Laurell, H.; Achtenhagen, L.; Andersson, S. The changing role of network ties and critical capabilities in an international new venture's early development. International Entrepreneurship and Management Journal, 2017, 13(1), 113-140.

62. Leonidou, L. C.; Katsikeas, C. S.; Piercy, N. F. Identifying managerial influences on exporting: past research and future directions. Journal of International Marketing, 1998, 6(2), 74-102.

63. Leonidou, L. C.; Katsikeas, C. S.; Samiee, S. Marketing strategy determinants of export performance: a meta-analysis. Journal of Business research, 2002, 55(1), 51-67.

64. Li, L.; Su, F.; Zhang, W.; Mao, J. Y. Digital transformation by SME entrepreneurs: A capability perspective. Information Systems Journal, 2018, 28(6), 1129-1157.

65. Liu, H.; Ke, W.; Wei, K. K.; Hua, Z. Effects of supply chain integration and market orientation on firm performance: Evidence from China. International Journal of Operations \& Production Management. 2013

66. Lonial, S. C.; Carter, R. E. The impact of organizational orientations on medium and small firm performance: A resourcebased perspective. Journal of Small Business Management, 2015, 53(1), 94-113. 
67. Louter, P. J.; Ouwerkerk, C.; Bakker, B. A. An inquiry into successful exporting. European Journal of Marketing, 1991, 25(6), $7-23$.

68. Luostarinen, R.; Gabrielsson, M. Globalization and marketing strategies of born globals in SMOPECs. Thunderbird International Business Review, 2006, 48(6), 773-801.

69. Mazzarol, T. SMEs engagement with e-commerce, e-business and e-marketing. Small enterprise research, 2015, 22(1), 79-90.

70. McDougall, P. P.; Oviatt, B. M. International entrepreneurship: the intersection of two research paths. Academy of management Journal, 2000, 43(5), 902-906.

71. McGuinness, N. W.; Little, B. The influence of product characteristics on the export performance of new industrial products. Journal of Marketing, 1981, 45(2), 110-122.

72. Mitręga, M. Dynamic marketing capability-refining the concept and applying it to company innovations. Journal of Business E Industrial Marketing. 2019

73. Mitrega, M.; Siemieniako, D.; Makkonen, H.; Kubacki, K.; Bresciani, S. Versatile capabilities for growth in the context of transforming countries: Evidence from Polish manufacturing companies. Journal of Business Research, 2021, 134, 156-170.

74. Moalla, E.; Mayrhofer, U. How does distance affect market entry mode choice? Evidence from French companies. European Management Journal, 2020, 38(1), 135-145.

75. Morgan, N. A.; Feng, H.; Whitler, K. A. Marketing capabilities in international marketing. Journal of International Marketing, 2018, 26(1), 61-95.

76. Mort, G. S.; Weerawardena, J. Networking capability and international entrepreneurship: How networks function in Australian born global firms. International Marketing Review. 2006

77. Murray, J. Y.; Gao, G. Y.; Kotabe, M. Market orientation and performance of export ventures: the process through marketing capabilities and competitive advantages. Journal of the academy of marketing science, 2011, 39(2), $252-269$.

78. Nason, R. S.; Wiklund, J. An assessment of resource-based theorizing on firm growth and suggestions for the future. Journal of management, 2018, 44(1), 32-60.

79. O'dwyer, M.; Gilmore, A.; Carson, D. Innovative marketing in SMEs. European Journal of Marketing. 2009

80. Pinho, J. C.; Prange, C. The effect of social networks and dynamic internationalization capabilities on international performance. Journal of World Business, 2016, 51(3), 391-403.

81. Pitelis, C. N.; Teece, D. J. The new MNE:'Orchestration'theory as envelope of 'Internalisation'theory. Management International Review, 2018, 58(4), 523-539.

82. Priem, R. L.; Butler, J. E. Is the resource-based "view" a useful perspective for strategic management research?. Academy of management review, 2001, 26(1), 22-40.

83. Reijonen, H. Do all SMEs practise same kind of marketing?. Journal of Small Business and Enterprise Development. 2010

84. Saleh, A. S.; Ndubisi, N. O. SME development in Malaysia: Domestic and global challenges. 2006

85. Santarelli, E.; D'altri, S. The diffusion of e-commerce among SMEs: Theoretical implications and empirical evidence. Small business economics, 2003, 21(3), 273-283.

86. Sarasvathy, S.; Kumar, K.; York, J. G.; Bhagavatula, S. An effectual approach to international entrepreneurship: Overlaps, challenges, and provocative possibilities. Entrepreneurship Theory and Practice, 2014, 38(1), 71-93.

87. Schweizer, R.; Vahlne, J. E,; Johanson, J. Internationalization as an entrepreneurial process. Journal of International Entrepreneurship, 2010, 8(4), 343-370.

88. Sepulveda, F.; Gabrielsson, M. Network development and firm growth: A resource-based study of B2B Born Globals. Industrial Marketing Management, 2013, 42(5), 792-804.

89. Sinkovics, N.; Sinkovics, R. R. The internet as an alternative path to internationalization?. International Marketing Review. 2013

90. Soinio, J.; Tanskanen, K.; Finne, M. How logistics-service providers can develop value-added services for SMEs: a dyadic perspective. The International Journal of Logistics Management. 2012 
91. Taiminen, H. M.; Karjaluoto, H. The usage of digital marketing channels in SMEs. Journal of Small Business and Enterprise Development. 2015

92. Tavengerwei, R. Using trade facilitation to assist MSMEs in E-commerce in developing countries. Journal of International Economic Law, 2018, 21(2), 349-378.

93. Teece, D. J. Explicating dynamic capabilities: the nature and microfoundations of (sustainable) enterprise performance. Strategic management journal, 2007, 28(13), 1319-1350.

94. Teece, D. J. The foundations of enterprise performance: Dynamic and ordinary capabilities in an (economic) theory of firms. Academy of management perspectives, 2014, 28(4), 328-352.

95. Teece, D. J.; Pisano, G.; Shuen, A. Dynamic capabilities and strategic management. Strategic management journal, 1997, 18(7), 509-533.

96. Terzi, N. The impact of e-commerce on international trade and employment. In Encyclopedia of E-Commerce Development, Implementation, and Management. 2016 (pp. 2271-2287). IGI Global.

97. Tsai, W., \& Ghoshal, S. Social capital and value creation: The role of intrafirm networks. Academy of management Journal, $1998,41(4), 464-476$.

98. Van Maanen, J. Reclaiming qualitative methods for organizational research: A preface. Administrative science quarterly, 1979, 24(4), 520-526.

99. Wang, F. Digital marketing capabilities in international firms: a relational perspective. International Marketing Review. 2020

100. Wang, W.; Ma, H. Export strategy, export intensity and learning: Integrating the resource perspective and institutional perspective. Journal of World Business, 2018, 53(4), 581-592.

101. Wiklund, J.; Shepherd, D. Entrepreneurial orientation and small business performance: a configurational approach. Journal of business venturing, 2005, 20(1), 71-91.

102. Williams, N. L.; Ridgman, T.; Shi, Y.; Ferdinand, N. Internationalization as interaction: A process perspective on internationalization from a small developing country. Thunderbird International Business Review, 2014, 56(2), 127-144.

103. Yamakawa, Y.; Peng, M. W.; Deeds, D. L. What drives new ventures to internationalize from emerging to developed economies?. Entrepreneurship theory and practice, 2008, 32(1), 59-82.

104. Yang, J.; Yang, N.; Yang, L.The Factors Affecting Cross-border E-commerce Development of SMEs-An Empirical Study. 2014, In WHICEB (p. 12).

105. Zou, S.; Stan, S. The determinants of export performance: a review of the empirical literature between 1987 and 1997. International marketing review. 1998 